\title{
A Literature Review On The Development Phases Of Hungarian Pig Industry (1945 - 1989) Part I
}

\author{
Vinkler Belane, PhD student \\ Budapest Metropolitan University, Heller Farkas Faculty of Tourism and \\ Economics, Institute of Economics, Hungary \\ Csilla Kalmar-Rimoczi, PhD student \\ College of Szolnok, Department of Tourism and Rural and Social \\ Development, Hungary \\ Beatrix Lenkovics, PhD student
}

Budapest Business University, Department of Hospitality, Hungary

doi: 10.19044/esj.2016.v12n20p288 URL:http://dx.doi.org/10.19044/esj.2016.v12n20p288

\begin{abstract}
Pig farming enjoys a significant tradition in Hungary and the pig industry plays a key role within the domestic animal husbandry sector. Raising pork has always played an important role in the domestic meat supply, but it has a crucial role in supplying the export markets. It can be concluded that our natural resources provide in themselves significant comparative advantages for us with a high proportion of arable land in agricultural use. Our social and economic endowments and potentials are also favourable for agricultural production and stock-raising. Our paper aims to employ financial data to describe the development of raising pig livestock in Hungary best characterized by its constant changes.

Part I summarises two periods describing the changes affecting the animal husbandry sector and their subsequent impact on the economy. On the one hand, it covers the period following World War II, from 1945 to 1965, describing the situation of the country and the farmers; on the other hand, it lists the economic achievements and their impact on the pig industry preceding the political-economic transition in the course of the years lasting from 1966 to 1989.
\end{abstract}

Keywords: Pig farming, production, competitiveness, EU, processing

\section{Literature review}

Lying in the heart of Central Europe, Hungary, because of her geographical location, climatic and natural endowments favourable even 
in international comparison (pleasant climate, top quality soil, knowledgable labour force) offer excellent conditions for grain cultivation which can establish the competitiveness of other agricultural sectors, too.

The need to reduce production costs, improve resistance capabilities and produce eco-friendly products prompted a part of the pig farmers to raise their animals afield in a natural environment under low-cost and practical conditions. Until the end of the 18th century, similarly to cattle and sheep, the main habitat for pigs was the field. Due to their omnivorous nature pig herds loved to roam the forests where they fed and fattened on mushrooms and oak and beech nuts (Incze, 2009).

The producton of domestic pig livestock was always characterized by periodical fluctuations that can be best illustrated by the inspection of the periods below:

$\square$ the impact of World War II and the following period (1945-1965)

a quick-paced development of animal husbandry preceding the transition (1966-1989).

Domestic figures clearly show the ratio of pig industry contributing to the total meat production of the country: the average of the pre-World War II years was close to 40\%, in 1990 it reached 48\%, and in 1994 it accounted for $43 \%$. The gross production value of animal husbandry in these years stood between 38-41 \%, at the same time, the share of animal husbandry in the total of agricultural production fluctuated between 43-46 \%. While global pig livestock figures between 1985 and1993 showed a trend of steady increase, in Hungary a drastic drop occurred in the pig livestock. Its impacts very evident; due to these changes our share in global production declined continuously from $1.04 \%$ to $0.72 \%$, which resulted in the loss of a significant part of our export markets. According to 1995 figures, domestic pig livestock came to almost half, $47.6 \%$ (4,669 thousand head) compared to the figure of 1983 (9,799 thousand head), however, when compared to the 1960 data, it reached 86 \% (Nábrádi, Szúcs, Balogh, 2000).

Although Hungary remained under Soviet domination in the period following 1956, the leadership of the country strived to create better conditions for ensuring people's livelihood and assist the development of agriculture by allowing them access to household plots and vineyards. Despite all this, in the period between 1958 and 1965, resulting from the severe decline in agricultural production the livelihood of 1.2 million people became precarious and they were forced to move to towns to earn a living there. (Veress \& Dunka, 2003).

It was in this period that the government introduced, besides the natural measurement of head for the registration of livestock as a resource, the term of livestock equivalents, which represented one animal of $500 \mathrm{~kg}$ live mass (or several animals amounting to $500 \mathrm{~kg}$ together). The result of 
this application was that the animal density of particular regions could be expressed in livestock equivalents and the data could be compared. For the expression of animals by indicators to allow for international comparisons the FAO worked out particular multipliers for different animal units (e.g. 0.2 for pigs).

Intensive pig farming in effect started spreading in Denmark in the 1960s with the first intensive pig farms equipped with special buildings and equipment to provide adequate conditions for raising pigs. They could ensure the farming of several hundred pigs at the same time and as a result raising pork at a high quality level. The intensive farming method and technology have spread to other countries of Europe and farms with small crop areas were also able to adapt to the new developments.

In the course of the twenty years between 1960 and 1980, significant changes occurred in the structure of animal husbandry. Parallel with the building of large-scale units, small household farms also sprang up in the villages. This production form became especially widespread in pig farming in the 1980s. Of the total pig livestock in the country $21 \%$ was produced in State Farms, $31 \%$ in Agricultural Co-operatives, while small household farms accounted for almost $48 \%$. The need to meet the requirements, the establishment of vertical and horizontal integration forms and the maintenance of existing market positions all required the improvement of quality. In this period, 11 million hogs were slaughtered in Hungary annually, of which 7 million was done by 19 State Meat Trading Companies, 2.4 million at slaughterhouses and meat processing plants, while another 2 million was done by households. Animal husbandry was the driving force of Hungarian agriculture producing the necessary forage for itself (Nábrádi et al., 2000).

A similar development took place in Denmark és Holland, too, but they could not produce their own fodder, most of the necessary forage was imported to provide for the demands of their animal husbandry sector.

In many countries of the world, but especially in European countries, pork represents an outstanding place in the food supply of the population. The demand has improved the standard of agricultural production, which in turn increased the consumption of pork. The Hungarian pig industry plays an outstanding role in raising pork since the cereals produced by agriculture constitute one of the main basic commodities of animal husbandry (Nábrádi et al., 2000).

When assessing the period between 1990 and 1997, it can be established that animal husbandry played an important role in Hungarian agribusiness, though its traditional structure was rather „grain oriented”. In the European countries with leading agrarian culture like Denmark and Holland the value of products coming from animal farming account for 65- 
$70 \%$ of total agricultural production. Considering the development of agricultu re in the $20^{\text {th }}$ century, the drop in livestock experienced in Hungarian animal farming in the past eight years can be termed as dramatic amounting to 1.6 million in livestock equivalents which exerted an impact on each sector (Horn, 1997). The decline of livestock reached a historic low which made an impact on the consumption of the population as well as the export markets and the situation was further worsened by other factors like:

- $\quad$ the obsolete, outdated equipment is unsuited to ensure the completion of the business cycle and competitiveness,

- co-operation and integration contacts in the market were eliminated,

- a significant shortage of resources, a persistent struggle with liquidity problems,

- upheaval in the export and domestic markets whose impacts are felt in several domestic sectors,

- difficulties in applying EU market specifications and regulations.

In Hungary $50 \%$ of the forage base produced was consumed by the pig industry and it is important to note that locally grown maize is lean in protein therefore the country needs to import protein fodder to supplement her stock. The constantly changing prices are not favourable to animal farmers and exert a heavy burden on the overhead costs of pig farmers (Csire, 1976).

Pig farming in Western Europe is conducted under very strict environmental and hygiene regulations. The EU in its member states regulates animal density because of its high environment pollution risk with an upper limit of the 31.5 animal unit equivalents for a 50 hectare farm (this limit represents 1,000 porkers). Farmers exceeding the animal density limits are taxed after those „organic manure producing units ” they keep over the 31.5 animal unit equivalents like in the case of 1,050 porker places accommodated in 50 hectares ( 1 unit $=7$ places) and they lose the subsidies and cannot apply for them.

Today animal farming sectors and farmers face a critical situation since they produce a lot of manure in raising the animals. In the regions where farmlands are small there is nowhere to despose of the manure which causes a serious problem. Nevertheless, farmers are forced to solve the problem of manure treatment in order to protect the environment.

\section{The impacts of World War II and the following period (1945-1965)}

The mangalitza kind best suited to domestic farming and foraging requirements according to statistic figures from 1911, made up for 92\% of the total pig livestock (Kralovánszky, 2009). 
After World War II, the majority of the most valuable pig stock cultures held in the manors were destroyed, only $36 \%$ of the earlier pig livestock survived in very bad condition estimated to total a 1.15 million head. The ratio of meat hogs in October 1947 stood at 28.2\%, but by October 1949 it was only $14.9 \%$, bringing a 50\% drop in the course of two years. It took long years for animal husbandry to recover from the destruction caused by the war (Baltay, 1983).

The period between 1945 and 1948, was the interim era of land reform when livestock keepers had to face a lot of difficulties in their efforts to improve the conditions for their animals. The agrarian reform including distribution and farm reallocation caused problems and was not accompanied with mechanization. Most members of the co-operatives organized from 1949 were former cottars who lacked the adequate information, showed poor management skills, were constantly in need of state support and were unable to conduct profitable production continuosly. At the same time, the number of manual workers increased as the labour force was needed to cultivate the growing area of arable land, fortify the dykes of rivers, and reconstruct the railway network. Hard physical work increased the population's consumption demand for animal fat and bacon. The impact of collectivization started in 1948 and continued after 1958, brought a significant fall in agricultural production resulting in the need to import food for the country's population (Veress \& Dunka, 2003).

A reorganization of the pig indudtry was initiated in 1945, with the foundation of the National Alliance of Animal Farming Organisations then in 1950 administration of animal husbandry was delegated to the county and district councils. The councils were overburdened with other tasks, could not pay enough attention to the issues of animal farming and implement effective changes. In 1951, the Directorate of Breeding Stock was set up which operated only for a few years and its role was taken over by the County Studbook Administrations in 1952. Between 1951 and 1954, the total, sow stock in Hungary amounted to 1,983 thousand heads, $62 \%$ of which were owned by private farmers, nearly $24 \%$ raised in state farms, while the rest owned by farmers' co-operatives.

The favourable changes expected of the constant reorganization measures did not bring a big increase of sow stock which was badly needed at the time and are clearly shown by the figures in Table 1 (Baltay, 1983). 
Table 1: Changes in the number of sow stock in Hungary between 1951and 1954 (figures in head)

\begin{tabular}{|c|c|c|c|c|}
\hline Years & \multirow{2}{*}{ Total no. of sows } & \multicolumn{3}{|c|}{ Ownership } \\
\cline { 3 - 5 } & & Private & State Farms & Co-ops \\
\hline 1951 & 471,000 & 327,000 & 99,000 & 45,000 \\
\hline 1952 & 540,000 & 326,000 & 131,000 & 83,000 \\
\hline 1953 & 466,000 & 230,000 & 150,000 & 86,000 \\
\hline 1954 & 506,000 & 340,000 & 95,000 & 71,000 \\
\hline Összesen & $1,983,000$ & $1,223,000$ & 475,000 & 285,000 \\
\hline
\end{tabular}

Source: Baltay Mihály (1983): Pigs and hybrids in Hungary

\section{Own construction}

The reorganization of farmers' co-operatives was officially completed on 17 February 1961, setting up three different types:

- type one: members of the co-operative completed dead work on the loam of the commonly-owned parcels,

- type two: crops produced by the community were distributed among the members according to an average,

- type three: independently of the assets contributed, members share in the incomes of the community in proportion to the work jointly completed.

The impacts of land distribution and reorganization required the introduction of new masures like the accessibility of new projects and the implementation of new investments all expected to contribute to the recovery and healthy operation of the counrty's economy. However, a major handicap entrepreneurship in the agrarian sector is the lack of capital and the low profitability of agribusinesses. The lack of financing sources great hinders their operations. Tendered sources are scarce and the banks' assessment of agrarian borrowers is not favourable. The whole market is characterized by slack demand, an ever-tightening competition and indecent behavior on behalf of a number of actors. Sales opportunities are limited and the bargaining position of private farms is weak (Vinkler, 2005).

Quick-paced development of the pig industry preceding the politicaleconomic transition (1966-1989)

When considering the period between 1950 and 1970 focusing on meat consumption, the consuming locally raised meat became dominant, primarily the consumption of pork. The volume of pig farming increased significantly and its gross production value within domestic animal farming reached $36 \%$. In the 1960 s, cattle farming claimed $38 \%$ of the total sector, but by the 1970s, it lost its leading position and was replaced bypig farming in Hungary. 
Pig livestock in the period between 1963 and 1968, fluctuated between 5.5-6.5 million head (comprising 460-570 thousand brood sows and 23-24 thousand boars. By the autumn of 1970, the total pig livestock reached 7.3 million (of which 604 thousand were brood sows). The number of livestock went through continual fluctuations due to changes in fodder prices and the impact of piglet sales opportunities, but despite all these factors, the increase was mostly due to household farming with $50 \%$ of sows being raised there while large farms accounted for only 42\% (Csire, 1976).

Based on the findings of Veress and Dunka (2003), it can be concluded that domestic crop production is more efficient than animal farming and a significant portion of arable land crop farming is internationally recognized and competitive. Thanks to the modernization of crop production specific yields improved but, in turn, it required the development of animal farming including the appropriate buildings and technical equipment. Between 1969 and 1972, the first livestock production program in pig farming was launched by Alfonz Alker (1925-1979) in Kaposvár, followed by the ÁKI pig farming pogram developed by Lajos Csire (1923-1974). The program set its objective to supply the whole population of the country with an adequate volume of meat products and be able to meet potential further market demands.

The development program of pig farming with government support was launched in Hungary in 1967, which greatly helped to create the conditions for industrial farming and modern forage supply systems in the sector. It was important that large farms were able to produce hybrid pigs for the industrial pork raising program which was a precondition for the profitable operation of pig plants. In the program to modernize outdated pig farms (1968-1975), almost 300 pig plants were built with government support with an annual capacity of 2.5 million of fatteners. Under ,industrylike” conditions they ensured „intensive” pork production which resulted in "winning a respectable place" for Hungary in the per capita meat production and the increase of specific yields both in crop and animal farming began. The development of pig farming greatly contributed to the more efficient production in agriculture (Böó, 1997).

As a result of modernization in the food industry, the mechanization of agricultural production became widespread with the application of modern machinery. In 1972, the launch of a specialization program in State Farms resulted in the increase of efficiency in pig plants. Although the number of porker places dropped from 1.8 million to 1.2 million between 1968 and 1975, it did not cause any problems in the meat supply of the population.

In order to increase pork production in the period between 1976 and 1980, The Livestock Trading and Meat industry Trust (ÁHT) bought up 2.5 million pigs per year, which made up for $38 \%$ of the average total pig 
purchases, and this figure went up to $42 \%$ in the last years of the period. In 1980, small household pig farmers were producing 5.2 million heads. By the middle of this year, the livestock kept by farmers' and other co-operatives fell back to 52\%. In contrast, business companies and plants held only 25\%, while private farmers' stock accounted for 44. In the five years of the program, the aim was to ensure the production of a balanced pig livestock by intervention purchases and sales of porklings or sow allocation campaigns, however, in the 1990s, these methods proved mostly ineffective and the number of pig livestock fell below 5 million (Széles, 1979).

\section{Factors further influencing the stability of safe pig farming}

- maintain the profitability of pig farming,

- $\quad$ ensure the continuous supply of fodder,

- $\quad$ ensure a lifeline of brood animals,

- develop sales markets,

- $\quad$ incorporate small-scale farming.

From the 1 January 1981 new system of purchase price regulations was introduced ensuring a roughly $10 \%$ profitability ratio for the end product. An important contribution to pork production was provided by the sow livestock raised in small household farms. The profitability of raising sows depends on the cost of production, the income levels you can earn from the sale of pigs, porkets and porklings in open trading. A primary and natural concern for farmers dealing with fattening is to ensure the supply of stock at the lowest possible prices.

In order to dissolve conflicts, the state intervenes with both direct and indirect methods to influence the production of sow keepers and fluctuations in the market by ensuring favourable conditions for production like:

- $\quad$ offering guarantees of sale by purchasing stocks all year round (market maintaining purchases),

- $\quad$ ensuring a steady level of income (maintaining price levels),

- $\quad$ ensuring local supply of fodder and pet food (cost reducing measures),

- $\quad$ ensuring an increase of livestock (by providing high quality breeding stock).

The market demand for pork offers an adequate guarantee for pig farmers. The solution for the development and stability of small household pig farming have a direct impact on livestock trading and the meat industry in general. To ensure profitability for farmers meat processing companies commission 1,000 co-operatives, 10 state farms and 50 general consumers' co-operatives to jointly organize pig farming and sales of small household 
farms involving all relevant organizations and institutions. It is important to note that all pig farmers are willing to continue this activity in the long run if the overheads and profitability of production can be calculated with certainty (Széles, 1979).

In the course of the $19^{\text {th }}$ century, animal farming went through a specialization process, either for specific animals or utilization directions. The species of animals were almost completely replaced and the technical development made a major impact on agricultural production. This led to increased production levels and provided a market for the population to purchase agricultural surplus produce (Juhász \& Zsembeli, 2005).

Studying the period between 1974 and 1975, the biggest pig livestock was registered in 1974 with 9.4 million heads of which 669 thousand were sows. The state continued to provide 50-70\% investment support for the creation of livestock spaces. The stocktaking registration conducted on 31 March 1983, exceeding the 1974 figures, found 9.86 million pigs and 749 thousand sows, which was almost double of the 1996 data amounting to only 5,289 thousand heads (Magda, 1998.).

Pork production was also double volume amounting to 700 thousand tons in 1985, when the number of livestock reached 10 million heads. A rapid fluctuation characteristic of pig farming makes it easier for the sector to better adjust to competitors and market conditions. Based on the indicators of the period, pig livestock between 1985 and 1990 fluctuated between 9 and 9.5 million. Despite the drive for large farm organization, small household farms still raised $50 \%$ of the pig stock while cattle stocks were stagnating. The pig farming sector plays an outstanding role in the local supply provided by Hungarian agriculture. The country's income from the export of prork products fluctuated between 450-500 US dollars (with a share of 20-22\% of total agrarian exports), contributing a great deal to the foreign balance of payment for the country. Between 1985 and 1990, it was clearly reflected in the product supply of local consumption which amounted to $78 \mathrm{~kg}$ of meat per capita of which $44 \mathrm{~kg}$ was made up by pork. The output of the pork production sector, of course, depended on the volume of the livestock and its structural composition (Pfau \& Széles, 2001).

Through the history of Hungary pig farming has always played an important role and can be termed as a traditional sector despite the fact that Hungarian agrarian policy tended to be more „grain-oriented”. The situation of the pig farming sector and its standard of production considering the consumption trends of the previous years made possible a 8$10 \mathrm{~kg}$ per capita increase in consumption annually. Global pork production between 1988 and 1993 grew by $10 \%$, in contrast, the number of domestic livestock and production of pork products fell by $35 \%$ with our share of global production dropping from $1.04 \%$ to $0.61 \%$. These figure clearly 
show that new investments and developments are needed which could serve as the basis for high quality pork production and competitiveness in the international market (Horn, 1997).

Since 1 January 1989, the European Union requires qualification of pig carcasses. The figures in the table below show the definition of different commercial categories (S-E-U-R-O-P) related to $100 \mathrm{~kg}$. In 1994, the Ministry of Agriculture in Hungary issued a decree to introduce the carcass qualification for slaughtered pigs and cattle.

The primary task is to meet the requirements of the $E$ (55-59\%) quality category. The highest categories representing the best lean meat qualified over S (60\%) are met by Denmark and Holland with 30\% of their production. One-third of France's production belongs to the E (55-59\%) category. Hungary belongs to the U (50-54\%) qualification with $33.8 \%$ of the production meeting the requirements. $\mathrm{O}$ and $\mathrm{P}$ are the lowest qualifications meaning technical rejects. (Pfau \& Széles, 2001)

One year after its introduction, Hungary already applied the EU pork qualification system for about 500,000 slaughter pigs which brought about a significant improvement in quality. The lean meat content of domestic pig slaughters reaches only $44 \%$. In contrast, European countries with modern and developed pig farming sectors can reach around 60\% lean meat value from which Hungary are still a long way to go. Comparing the specific indicators of domestic slaughter pigs to the ones of leading EU countries, Hungary's stay below them which also show the impact of production conditions on competitiveness.

Table 2 shows the qualification and production distribution of pork in percentage.

Table 2: Qualification and production distribution of pork in Hungary (\%)

\begin{tabular}{|c|c|c|}
\hline Quality category & $\begin{array}{c}\text { Lean meat content for } \\
100 \mathrm{~kg} \text { carcass pig, } \mathrm{kg}\end{array}$ & $\begin{array}{c}\text { Production distribution in } \\
\text { Hungary }\end{array}$ \\
\hline S & Over 60 (lean meat) & - \\
\hline E & $55-59$ & 15.3 \\
\hline U & $50-54$ & 33.8 \\
\hline R & $45-49$ & 30.6 \\
\hline O & $40-45$ & 14.7 \\
\hline P & 40 alatt & 5.7 \\
\hline
\end{tabular}

Source: Nábrádi András, Szücs István, Balogh Péter (2000): A sertéshústermelés gazdasági kérdései. Own construction

Hungary has proved that she is able to secure forage for over $\mathbf{1 0}$ million pigs if need be, and ensure for the processing of livestock applying the most modern technology. The pig farming sector started a growth process and was able to appear and hold its position on the global market with quality products. As a result of the achievements in animal farming, volumes in fodder production also increased and had a beneficial impact on 
crop production in general. The increase in production was greatly assisted by the formation and operation of integration contacts - involving producers, meat industry, large and small-scale farms alike. (Magda, 1998)

\section{References:}

Baltay Mihály (1983): Magyarországi sertésfajták és - hibridek. Mezőgazdasági Kiadó, Budapest, pp 29-30.

Böő István (1997): A kisüzemi sertéshústermelés gyakorlata. Mezőgazdasági Szaktudás Kiadó, Budapest, pp 35, 61.

Csire Lajos (1976) A sertés gazdasági jelentősége. Horn Artúr szerk., (1976): Állattenyésztés III. kötet Mezőgazdasági Kiadó, Budapest, 13 p.

Horn Péter (1997): Állattenyésztés-takarmány gazdálkodás-állategészségügy Tanulmány. Glatz Ferenc szerk. A magyar agrárgazdaság jelene és kilátásai. Magyar Tudományos Akadémia, Budapest, pp 71-74.

Incze Péter (2009):A tartási költségek mérséklése (Sertések Szabad tartása) Incze $\quad$ Péter 2009. augusztus18., kedd, Gazdakör.http://www.3szek.ro/load/cikk/21823/a_tartasi_koltsegek_mersekl ese_sertesek_szaba d_tartasa_-_incze_peter

Juhász Csaba, Zsembeli József (2005): Az Európai Unió mezőgazdasága. Szaktudás Kiadó Ház, Budapest, pp 17-29.

Kralovánszky U. Pál (2009): Mi történik velünk: Magyar Állattenyésztés (1918-2008) Állattenyésztés és Takarmányozás Vol.58 (No.1.) pp 1-5.

Nábrádi András, Szücs István, Balogh Péter (2000): A sertéshústermelés gazdasági kérdései. Mezőgazdasági Szaktudás Kiadó, Budapest, pp.7-23. 40.

Magda Sándor (1998): Mezőgazdasági vállalkozások szervezése és ökonómiája. Mezőgazdasági Szaktudás Kiadó, Budapest pp 461-469.

Pfau Ernő, Széles Gyula (2001): Mezőgazdasági üzemtan II. Mezőgazdasági Szaktudás Kiadó, Budapest, pp 378-385.

Széles István (1979): A kisüzemi sertéstermelés helyzete és fejlesztése. Basa János, Gelei István szerk. Gazdaságos sertéstartás a ház körül. Mezőgazdasági Kiadó, Budapest, pp 5-9.

Veress László, Dunka Béla (2003): Fejezetek a magyar állattenyésztés történetéből. Debreceni Egyetem Agrártudományi Centrum Mezőgazdaságtudományi Kara és a Mezőgazda Kiadó (Nemzeti Kulturális Alapprogram támogatta), pp. 94-105.

Vinkler Béláné (2005): A kis-és középvállalkozások helyzete napjainkban. Dunaújvárosi Főiskola Közleményei XXVII/II. pp 639-642. 